\title{
Pengaruh Kualitas Pelayanan terhadap Kepuasan Mahasiswa Pengguna Jasa Perpustakaan Pusat Universitas Merdeka Madiun
}

\author{
Mintarti Indartini \\ Fakultas Ekonomi, Universitas Merdeka Madiun, Jl.Serayu 79, Madiun, 63133 \\ E-mail: mintarti@unmer-madiun.ac.id
}

\begin{abstract}
Higher education institutions such as universities in the era of technology and information required to improve services in the field of education by using information technology quickly and precisely, so the college can improve its performance. Especially in terms of services in the academic field and as motivate colleges to transform the structure and strategy of development of ed ucational facilities and prerequisites in order to become a superior higher education institutions, making progress, able to compete and trusted by stackholder.The purpose of this study were (1) To analyze the influence of tangible, reliability, responsiveness, assurance and empathy variable partially on student satisfaction of library service user of Universitas Merdeka Madiun. (2) To analyze the influence of tangible, reliability, responsiveness, assurance and empathy variable simultaneously toward student satisfaction of library service user of Universitas Merdeka Madiun. The result of research show that (1) Tangible partially affect the satisfaction of students of central library user of Universitas Merdeka Madiun. (3) Partial responsiveness affects student satisfaction of library user of University of Merdeka Madiun University (4) Assurance partially has no effect on student satisfaction of library user of University of Merdeka Madiun. (5) Emphaty partially affect student satisfaction of library user of University of Merdeka Madiun and (6) Tangible, reliability, responsiveness, assurance and emphaty simultaneously influence student satisfaction of library user of University of Merdeka Madiun.
\end{abstract}

Keywords —: Tangible; Reliability; Responsiveness; Assurance; Emphaty.

\section{PENDAHULUAN}

Animo masyarakat Indonesia terhadap pendidikan sangat dirasakan. Rata-rata tingkat pendidikan akhir yang dimiliki oleh masyarakat Indonesia terendah/minimal kelas sembilan atau telah lulus tingkat Sekolah Menengah Pertama (SMP). Hal ini menunjukan bahwa tingkat kesadaran masyarakat tentang pendidikan sangat tinggi. Era modern sekarang dituntut adanya suatu tingkat pendidikan dan informasi yang lebih cepat dan tepat. Tentu harus ditunjang adanya sarana dan prasaran yang memadai dan lengkap.

Apalagi lembaga pendidikan tinggi seperti perguruan tinggi dalam era teknologi dan informasi sekarang ini dituntut untuk meningkatkan pelayanan di bidang pendidikan dengan menggunakan teknologi informasi yang cepat dan tepat, sehingga membuat perguruan tinggi bisa meningkatkan kinerjanya. Khususnya dalam hal pelayanan di bidang akademik serta memotivasi lembaga perguruan tinggi untuk melakukan transformasi struktur dan strategi pengembangan sarana dan prasara pendidikan agar dapat menjadi lembaga pendidikan tinggi yang unggul, berkemajuan, mampu bersaing dan terpercaya serta banyak dicari oleh stakeholder.

Pelayanan bertujuan membangun suatu kerja sama dengan pihak lain yang saling menguntungkan kedua belah pihak dalam jangka panjang, dalam bentuk kegiatan sosial yang berguna untuk membantu orang lain. Pelayanan yang baik merupakan suatu bentuk pelayanan yang dapat memahami dan mengerti akan kehendak, keinginan dan kebutuhan konsumen. Pelayanan berusaha memberi nilai lebih kepada semua pelanggan, maka akan tercipta adanya kualitas pelayanan yang cepat dan tepat. Kotler dikutip oleh Assegaff (2009) bahwa kualitas harus di mulai dari kebutuhan pelanggan dan berakhir pada persepsi pelanggan. Assegaff (2009) hal ini berarti bahwa citra kualitas yang baik tidak berdasarkan persepsi penyedia jasa, akan tetapi berdasarkan persepsi pelanggan.

Lembaga perguruan tinggi terdiri dari beberapa unit pelayanan jasa. Salah satu unit pelayanan jasa tersebut adalah perpustakaan. Lembaga Perguruan Tinggi Universitas Merdeka Madiun merupakan salah satu lembaga pendidikan tinggi di Madiun yang dilengkapi pula unit pelayanan jasa perpustakaan yakni Perpustakaan Pusat Universitas Merdeka Madiun. Perpuskaan Pusat Universitas Merdeka Madiun memberikan pelayanan jasa kepada mahasiswa. Kebutuhan mahasiswa terhadap ilmu pengetahuan dan media pendidikan lainnya merupakan salah satu bentuk sarana penunjang akademik yang dibutuhkan mahasiswa. Hampir semua insan akademik membutuhkan jasa perpustakaan untuk menunjang aktivitasnya dalam menempuh jenjang pendidikan atau sebagai sarana untuk mencari ilmu pengetahuan. Perpustakaan Pusat Universitas Merdeka Madiun sebagai salah satu unit jasa yang mempunyai harapan agar perpustakaan dapat menjadi pusat informasi dan pusat pendidikan yang unggul dan berkemajuan bagi semua mahasiswa.

Pelayanan jasa yang diberikan oleh unit perpustakaan Pusat Universitas Merdeka Madiun kepada mahasiswa adalah sebuah pelayanan dengan harapan akan tercipta adanya kepuasan mahasiswa sebagai pengguna jasa. Menciptakan kepuasan mahasiswa melalui pelayanan untuk menciptakan image positif bagi pengguna jasa. Perpustakaan Universitas Merdeka Madiun apabila bisa 
Website : http://ekomaks.unmermadiun.ac.id/index.php/ekomaks

mempertahankan citra baik, berkesan positif pada mahasiswa dan dapat memenuhi keinginan serta kebutuhan mahasiswa maka mahasiswa akan kembali berkunjung dan memberikan suatu rekomendasi kepada orang lain atau mahasiswa lain agar mau berkunjung ke Perpustakaan Pusat Universitas Merdeka Madiun.

Pelaksanaan dalam memberikan pelayanan yang memuaskan kepada mahasiswa sesuatu hal yang tidak mudah dilakukan, akan ada suatu masalah yang dihadapi yang Maka sangatlah diperlukan adanya suatu perencanaan yang matang dan jelas, sarana dan prasarana atau fasilitas yang memadai agar dapat menciptakan kepuasan mahasiswa. Karena kualitas pelayanan dengan kepuasan mahasiswa merupakan suatu hubungan yang sangat erat sekali. Untuk menciptakan mahasiswa merasa tertarik, senang dan mendapatkan suatu tingkat kepuasan pelayanan jasa perpustakaan sebaiknya pihak manajemen pengelola perpustakaan Pusat Universitas Merdeka Madiun melakukan kegiatan identifikasi keinginanan dan kebutuhan mahasiswa.

Baik tidaknya kualitas jasa atau pelayanan sangat dipengaruhi oleh kemampuan dari penyedia jasa dalam memenuhi harapan konsumen secara konsisten, (Parasuraman dalam Griselda dan Panjaitan, 2007). Jika pelayanan jasa antara kenyataan dengan harapan menjadi lebih baik, maka akan timbul persepsi dari mahasiswa bahwa kualitas pelayan jasa yang telah diberikan tersebut berkesan baik atau positif.

Bagi pihak manajemen pengelola perpustakaan pusat Universitas Merdeka dengan adanya kekurangan atau keterbatasannya maka harus berusaha meningkatkan kinerjanya agar mahasiswa mendapatkan kepuasan dan berkunjung kembali, usaha yang harus dilakukan adalah menentukan program unggulan/prioritas dalam bidang pelayanan yang berkualitas. Karena kualitas pelayanan akan berpengaruh terhadap tingkat kepuasan pelanggannya.

\section{A. Kualitas Pelayanan}

Gronroos dalam Tjiptono dan Chandra (2005) pelanggan tidak hanya sekedar membeli barang atau jasa, namun mereka membeli manfaat yang diperoleh barang dan jasa yang telah dibeli. Konsumen membeli atas barang yang ditawaran meliputi layanan, informasi, perhatian personal, dan komponen lainnya. Penawaran semacam ini mencerminkan layanan yang diberikan bagi pelanggan dan customer-perceived service tersebut memberikan nilai tambah bagi setiap pelanggan. Perusahaan selalu berusaha menawarkan pelayanan bagi pelanggan, terlepas dari hal apa pun bentuk produk yang di berikan.

Menurut Edvardsson dalam Griselda dan Panjaitan (2007) kualitas adalah bagaimana mencari tahu apa yang menciptakan nilai bagi konsumen dan perusahaan harus menberikan nilai itu. Perusahaan harus dapat mengerti konsumennya dan bagaimana mendefinisikan keinginan konsumen tersebut dengan benar. Sedangkan layanan adalah berbagai tindakan dan kinerja yang di tawarkan suatu produk kepada orang lain yang pada dasarnya tidak dapat di lihat dan tidak menghasilkan hak milik terhadap sesuatu.

Menurut Parasuraman dalam Griselda dan Panjaitan (2007) faktor utama yang mempengaruhi pelayanan atau jasa adalah jasa yang diharapkan dan diterima. Apabila harapan dan kenyataan yang diterima oleh konsumen sama atau menjadi lebih baik, maka pelanggan akan mempunyai persepsi bahwa kualitas jasa tersebut baik atau positif dan sebaliknya. Baik tidaknya kualitas jasa atau pelayanan sangat dipengaruhi oleh kemampuan dari penyedia jasa dalam memenuhi harapan pelanggan secara konsisten.

Griselda dan Panjaitan (2007) mendefinisikan kualitas jasa merupakan suatu ukuran seberapa bagus tingkat layanan yang diberikan mampu serta sesuai dengan ekspektasi pelanggan. Berdasarkan definisi ini, suatu kualitas pelayanan bisa diwujudkan dengan cara pemenuhan kebutuhan dan keinginan pelanggan serta ketepatan penyampaikannya dalam upaya mengimbangi harapan pelanggan.

Kotler dalam Griselda dan Panjaitan (2007) Kualitas layanan harus dimulai dari kebutuhan pelanggan dan berakhir dengan kepuasan pelanggan serta persepsi positif terhadap kualitas pelayanan. Sebagai pihak yang mengkonsumsi jasa, pelanggan yang manilai tingkat kualitas jasa sebuah perusahaan. Persepsi dan interaksi dengan pelanggan dalam memberikan pelayanan akan menentukan suatu bentuk evaluasi kualitas pelayanan. Konsequensinya jasa yang sama bisa dinilai berlainan oleh konsumen yang berbeda.

Menurut Tjiptono (2014) bahwa kualitas pelayanan ditentukan oleh lima faktor yakni:

1) Berwujud(Tangible)

Berupa penampilan fisik, peralatan dan berbagai materi yang terlihat yang dapat dinilai dengan baik.

2) Empati(Emphaty)

Kesediaan karyawan dalam menjalin relasi, komunikasi yang baik, perhatian pribadi dan pemahaman atas kebutuhan individual pelanggan.

3) Daya tanggap(Responsiveness)

Kemauan dan kemampuan dari karyawan memberikan pelayanan secara cepat dan tanggap. Kesigapan para karyawan untuk memenuhi keinginan konsumen dengan tanggap dan ramah.

4) Keandalan(Reliability)

Kemampuan untuk memberikan layanan dengan segera, akurat, konsisten dan memuaskan.

5) Jaminan (Assurance)

Mencakup pengetahuan, kompetensi, kesopanan dan sifat dapat dipercaya yang dimiliki para staff mengenai janji yang diberikan, bebas dari bahaya, resiko atau keragu-raguan.

Gorvin dalam Tjiptono dan Chandra (2005) mengemukakan ada delapan dimensi kualitas yang bisa digunakan sebagai kerangka perencanaan dan analisis strategik. Berikut ini adalah deskripsi dimensi tersebut. 
Website : http://ekomaks.unmermadiun.ac.id/index.php/ekomaks

1) Kinerja (performance)

Karakteristik operasi pokok dan produk inti yang dibeli, misalkan kecepatan, konsumsi bahan bakar, kemudahan dan kenyamanan, dan sebagainya.

2) Fitur atau ciri-ciri tambahan (features)

Karakteristik sekunder atau pelengkap. Misalkan kelengkapan interior dan eksterior seperti AC, soud system dan sebagainya.

3) Reliabilitas (reliability)

Kemungkinan hasil akan mengalami kerusakan atau gagal di pakai misalnya mobil tidak sering mogok.

4) Kesesuaian dengan spesifikasi (conformance to specifications)

Sejauh mana karakteristik desain dan operasi memenuhi standar keamanan dan emisi terpenuhi.

5) Daya tarik (durability)

Berkaitan dengan berapa lama produk tersebut dapat terus digunakan. Umumnya daya tahan mobil buatas Amerika Serikat lebih baik dibandingkan Korea selatan.

6) Service ability

Meliputi kecepatan, kompetensi, kenyamanan, kemudahan, direparasi serta penanganan keluhan secara memuaskan.

7) Estetika

Daya tarik produk terhadap pancaindra, misalkan bentuk fisik mobil yang menarik, model yang artistik, warna, dan sebagainya.

8) Kualitas yang di persepsikan (perceived quality)

Citra dan reputasi produk serta tanggung jawab perusahaan terhadapnya. Umumnya orang akan mempersepsikan merek Mercedes, rool Royce, porche dan BMW sebagai jaminan mutu.

Sementara itu, Parasuraman, Zeithaml, dan Berry dalam Tjiptono dan Chandra (2005) ada lima dimensi pokok jasa:

1) Reliabilitas (reliability)

Berkaitan dengan kemampuan perusahaan untuk memberikan layanan yang akurat sejak pertama kali tanpa membuat kesalahan apapun dan menyampaikan jasanya sesuai dengan waktu yang di sepakati.

2) Daya tanggap (responsiveness)

Berkaitan dengan kesediaan dan kemampuan para karyawan untuk membantu para pelanggan dan merespon permintaan mereka, serta menginformasikan kapan jasa akan di berikan dan kemudian memberikan jasa secara cepat.

3) Jaminan (assurance)

Yakni perilaku karyawan mampu menumbuhkan kepercayaan pelanggan terhadap perusahaan dan perusahaan dapat menciptakan rasa aman bagi para pelanggannya.

4) Empati (emphaty), berarti perusahaan memahami masalah para pelangganya dan bertindak demi kepentingan pelangga, serta memberikan perhatian personal kepada para pelanggan dan memiliki jam operasi yang nyaman.

5) Bukti fisik (tangible)

Berkenaan dengan daya tarik fasilitas fisik, perlangkapan, dan materi yang di gunakan perusahaan serta penampilan karyawan.

Beberapa penjelasan para ahli tentang dimensi kualitas pelayanan di atas, dapat disimpulkan bahwa kualitas pelayanan dapat memberikan kepuasan kepada para pelanggan. Dimensi Kualitas pelayanan tersebut dipengaruhi oleh banyak faktor penentu diantaranya bukti fisik (tangible), keandalan (reliability), ketanggapan (responsiveness), jaminan (assurance) dan empati (emphaty).

\section{B. Kepuasan Konsumen}

Meningkatkan kepuasan konsumen adalah salah satu tujuan perusahaan atau organisasi yang menyediakan jasa terhadap kepuasan konsumen. Jika konsumen merasakan kepuasan, maka peluang perusahaan memperoleh keuntungan semakin besar karena konsumen akan melakukan transaksi atau hubungan kembali dengan penyedia jasa. Namun sebaliknya, jika konsumen merasa tidak puas dengan pelayanan yang diberikan, maka citra perusahaan jasa akan menjadi negatif dan menjalin hubungan jangka panjang pelanggan semakin berkurang. Cadotte, Woodruff dan Jenkins dalam Tjiptono dan Chandra, (2005) menyatakan bahwa kupuasan sebagai perasaan yang timbul setelah mengevaluasi pengalaman pemakaian produk.

Kotler dalam Griselda dan Panjaitan (2007) kepuasan adalah perasaan senang atau kecewa seseorang yang berasal dari perbandingan antara kesannya terhadap kinerja suatu produk serta harapannya akan produk tersebut. Apabila kinerja yang ada, berada di bawah harapan maka konsumen akan merasa kecewa. Sebaliknya, bila kinerja berada di atas harapan, maka konsumen akan merasa puas. Jadi dapat dilihat bahwa, kepuasan pelanggan dipengaruhi oleh harapan pelanggan dan kinerja perusahaan.

Menurut Kotler \& Keller (2012), kepuasan adalah perasaan puas atau kecewa seseorang yang dihasilkan dari perbandingan performa produk atau hasil dengan ekspektasi. Jika performanya kurang dari ekspektasi maka pelanggan akan kecewa dan jika sesuai dengan ekspektasi konsumen akan merasa puas.

Menurut Assegaff (2009), kepuasan konsumen adalah suatu ukuran yang merefleksikan antara struktur, proses dan hasil akhir pelayanan. Kepuasan konsumen di pandang sebagai konsep multi dimensional yang melibatkan biaya, kemudahan sarana, aspek teknis dan interpersonal serta hasil akhir. Kepuasan juga dapat di pertimbangkan sebagai hubungan antara harapan dan pengalaman, dimana semakin dekat dengan harapan akan semakin puas konsumen. 
Website : http://ekomaks.unmermadiun.ac.id/index.php/ekomaks

Kepuasan pelanggan adalah perasaan senang atau kecewa yang muncul setelah membandingkan kinerja (hasil) produk yang dipikirkan terhadap kinerja (atau hasil) yang diharapkan. Hal ini menunjukan apabila kinerja produk tidak sesuai dengan harapan konsumen dan bila harapan yang ditetapkan terlalu rendah, maka konsumen tersebut akan merasa tidak puas dan berujung kecewa, jika kinerja sesuai dengan harapan maka konsumen akan merasa puas, namun apabila kinerja produk melampaui harapan, maka konsumen akan merasa gembira dan sangat puas.

Berbagai argumentasi para ahli tersebut, maka dapat di simpulkan bahwa kepuasan konsuman merupakan suatu kondisi yang di tunjukan olah pelanggan setelah menggunakan jasa atau pelayanan tersebut. Bila responnya positif maka konsumen merasa puas dan akan melakukan transaksi ulang. Namun sebaliknya, bila konsumen merasa tidak senang atau kecewa terhadap pelayanan yang di terimanya, maka konsumen tergolang tidak puas dan mempunyai image negative terhadap pelayanan tersebut.

Menurut Tjiptono (2014), kepuasan berasal dari bahasa Latin "Satis" yang berarti cukup baik, memadai dan "Facio" yang berarti melakukan atau membuat. Secara sederhana kepuasan bisa diartikan sebagai upaya pemenuhan sesuatu atau membuat sesuatu memadai.

Enam konsep inti mengenai objek pengukuran kepuasan pelanggan:

1) Kepuasan pelanggan keseluruhan (overall customer satisfaction)

2) Dimensi kepuasan pelanggan

3) Konfirmasi harapan (confirmation of expectation)

4) Niat beli ulang (repurchase intention)

5) Kesediaan untuk merekomendasi (willingness to recommend)

6) Ketidakpuasan pelanggan

Dimensi Kepuasan Pelanggan, hal yang dapat mempengaruhi kepuasan pelanggan dapat dilihat dari ukuran atau dimensi kepuasan pelanggan menurut Kotler \& Keller (2012), yaitu

1) Tetap setia

Konsumen yang terpuaskan cenderung akan menjadi setia atau loyal. Konsumen yang puas terhadap produk yang dikonsumsinya akan mempunyai kecenderungan untuk membeli ulang dari produsen yang sama.

2) Membeli produk yang ditawarkan

Keinginan untuk membeli produk atau makanan lain yang ditawarkan karena adanya keinginan untuk mengulang pengalaman yang baik dan menghindari pengalaman yang buruk.

3) Merekomendasikan produk

Kepuasan merupakan faktor yang mendorong adanya komunikasi dari mulut ke mulut (word of mouth communication) yang bersifat positif. Hal ini dapat berupa rekomendasi kepada calon konsumen yang lain dan mengatakan hal-hal yang baik mengenai produk dan perusahaan yang menyediakan produk.

4) Bersedia membayar lebih

Konsumen cenderung menggunakan harga sebagai patokan kepuasan, ketika harga lebih tinggi konsumen cenderung berfikir kualitas menjadi lebih tinggi juga.

5) Memberi masukan

Walaupun kepuasan sudah tercapai, konsumen selalu menginginkan yang lebih lagi, maka konsumen akan memberi masukan atau saran agar keinginan mereka dapat tercapai.

Hawkins dan Lonney dikutip dalam Tjiptono (2014), atribut pembentuk kepuasan terdiri dari:

1) Kesesuaian harapan

Merupakan tingkat kesesuaian antara kinerja produk yang diharapkan oleh pelanggan dengan yang dirasakan oleh pelanggan, meliputi:

a. Produk yang diperoleh sesuai atau melebihi dengan yang diharapkan.

b. Pelayanan oleh karyawan yang diperoleh sesuai atau melebihi dengan yang diharapkan.

c. Fasilitas penunjang yang didapat sesuai atau melebihi dengan yang diharapkan.

2) Minat berkunjung kembali

Merupakan kesedian pelanggan untuk berkunjung kembali atau melakukan pembelian ulang terhadap produk terkait, meliputi:

a. Berminat untuk berkunjung kembali karena pelayanan yang diberikan oleh karyawan memuaskan.

b. Berminat untuk berkunjung kembali karena nilai dan manfaat yang diperoleh setelah mengkonsumsi produk.

c. Berminat untuk berkunjung kembali karena fasilitas penunjang yang disediakan memadai.

3) Kesediaanmerekomendasikan

Merupakan kesediaan pelanggan untuk merekomendasikan produk yang telah dirasakannya kepada teman atau keluarga, meliputi:

a. Menyarankan teman atau kerabat untuk membeli produk yang ditawarkan karena pelayanan yang memuaskan.

b. Menyarankan teman atau kerabat untuk membeli produk yang ditawarkan karena fasilitas penunjang yang disediakan memadai.

c. Menyarankan teman atau kerabat untuk membeli produk yang ditawarkan karena nilai atau manfaat yang didapat setelah mengkonsumsi sebuah produk jasa. 
Website : http://ekomaks.unmermadiun.ac.id/index.php/ekomaks

\section{Hubungan Kualitas Pelayanan Terhadap Kepuasan Pelanggan}

Menurut Kotler \& Keller (2012) "Product and service quality, customer satisfaction, and company profitability are intimately connected. Higher levels of quality result in higher levels of customer satisfaction, which support higher prices and often lower costs". Yang berarti produk dan kualitas pelayanan kepuasan pelanggan dan profitabilitas perusahaan berhubungan erat. Semakin tinggi hasil kepuasan menghasilkan tingkat kepuasan pelanggan yang lebih tinggi, dimana membantu tingginya harga dan pengurangan pengeluaran.

Menurut Zeithaml \& Bitner yang dikutip kembali oleh Tjiptono (2014), ada empat faktor utama yang sering kali menjadi penyebab dalam timbulnya masalah komunikasi dalam bidang jasa. Oleh sebab itu ia merekomendasikan empat strategi utama komunikasi pemasaran jasa yang salah satunya adalah dengan meningkatkan edukasi pelanggan. Bentuk dari edukasi pelanggan yang dibutuhkan antara lain: menyiapkan pelanggan untuk proses jasa, mengkonfirmasikan kinerja dengan standart dan ekspektasi, mengklarifikasikan ekspektasi setelah penjualan, dan mendidik pelanggan agar menghindari periode permintaan puncak.

Melalui edukasi ini diharapkan pelanggan dapat mampu memahami pelayanan yang diberikan dan menghindari kemungkinan kekecewaan di kemudian hari yang disebabkan oleh melonjaknya ekspektasi pelanggan yang berdampak negatif.

Dikutip oleh Tjiptono (2014) dari Parasuraman dan Hoffman\& Bateson bahwa banyak akademisi dan peneliti yang sepakat bahwa kepuasan pelanggan merupakan ukuran spesifik untuk setiap transaksi, situasi dan interaksi yang bersifat jangka pendek, sedangkan kualitas jasa merupakan sikap yang dibentuk dari evaluasi keseluruhan terhadap kinerja perusahaan dalam jangka panjang.

Menurut Cronin dan Taylor yang dikutip oleh Tjiptono (2014), salah satu kemungkinan hubungan yang banyak disepakati adalah bahwa kepuasan membantu konsumen dalam merevisi persepsinya terhadap kualitas jasa. Hoofman dan Bateson yang dikutip oleh Tjiptono menuliskan dasar pemikirannya tentang hubungan kualitas jasa dan kepuasan konsumen antara lain:

1) Bila konsumen tidak memiliki pengalamn sebelumnya dengan suatu perusahaan, maka persepsinya terhadap kualitas jasa perusahaan tersebut akan didasarkan pada ekspektasinya.

2) Interaksi (service encounter) berikutnya dengan perusahaan tersebut akan menyebabkan konsumen memasuki proses dikonfirmasi dan merevisi persepsinya terhadap kualitas jasa.

Setiap interaksi tambahan dengan perusahaan itu akan memperkuat atau sebaliknya malah mengubah persepsi pelanggan terhadap kualitas jasa. Persepsi terhadap kualitas jasa yang telah direvisi memodifikasi minat beli konsumen terhadap pembelian di masa datang.

\section{METODOLOGI PENELITIAN}

\section{A. Jenis Penelitian}

Adapun jenis penelitian dalam penelitian yang dilakukan ini adalah penelitian kuantitatif dengan pendekatan eksplanasi yaitu model penelitian yang bertujuan untuk mengetahui hubungan antara dua buah variabel atau lebih.

\section{B. Populasi, Sampel dan Teknik Pengambilan Sampel}

Populasi dalam penelitian ini adalah semua pengunjung perpustakaan pusat Universitas Merdeka Madiun yaitu mahasiswa Universitas Mendeka Madiun maupun dari pihak luar Universitas Merdeka Madiun. Maka populasi dalam penelitian ini tidak diketahui jumlahnya. Pada penelitian ini jumlah populasi tidak diketahui dengan pasti sehingga untuk menghitung jumlah sampel minimum yang dibutuhkan menggunakan formula Lemeshow. Berdasarkan hasil perhitungan jumlah sampel 96 orang. Teknik pengambilan sampel dalam penelitian ini menggunakan convenience sampling.

\section{Teknik Analisa Data}

Karena data yang digunakan dalam penelitian ini berbentuk kuantitatif maka teknik analisa data dilakukan secara statistik dengan metode Analisa Regresi Linier Berganda. Kemudian dilakukan Uji Determinasi $\left(\mathrm{R}^{2}\right)$, Uji Hipotesis, menentukan Variabel Dominan.

\section{III.HASIL DAN PEMBAHASAN}

\section{A. Regresi Linier Berganda}

Tabel koefisien dari hasil penelitian menunjukan bahwa:

Tabel 1

Koefisien Regresi Linier Berganda

\begin{tabular}{|c|c|c|c|c|c|}
\hline \multirow{2}{*}{ Model } & \multicolumn{2}{|c|}{$\begin{array}{c}\text { Unstandardized } \\
\text { Coefficients }\end{array}$} & $\begin{array}{c}\text { Standardized } \\
\text { Coefficients }\end{array}$ & $\mathbf{t}$ & Sig. \\
\cline { 2 - 6 } & $\mathbf{B}$ & Std. Error & Beta & & \\
\hline $1 \begin{array}{c}\text { (Constant } \\
\text { ) }\end{array}$ & -.633 & .196 & & -3.234 & .002 \\
\hline
\end{tabular}


Website : http://ekomaks.unmermadiun.ac.id/index.php/ekomaks

\begin{tabular}{c|c|c|c|c|c|}
$\mathrm{X} 1$ & .286 & .063 & .281 & 4.538 & .000 \\
$\mathrm{X} 2$ & .419 & .063 & .424 & 6.654 & .000 \\
$\mathrm{X} 3$ & .505 & .180 & .564 & 2.803 & .004 \\
$\mathrm{X} 4$ & -.221 & .160 & -.269 & -1.382 & .170 \\
$\mathrm{X} 5$ & .209 & .056 & .282 & 3.738 & .000 \\
a. Dependent Variable: Y
\end{tabular}

Analisis dari Tabel 1 menunjukan bahwa persamaan Regresi Linier Berganda secara statistik adalah $\mathrm{Y}=0,533+0,286 \mathrm{X}_{1}+$ $0,419 X_{2}+0,505 X_{3}-0,221 X_{4}+0,209 X_{5}$

\section{B. Distribusi t (t student)}

Hasil analisis pada Tabel 1 menunjukkan bahwa (1) Tingkat signifikansinya variabel tangeble sebesar 0,000 < dari 0,05 dengan hipotesis yang menyatakan bahwa Tangible secara parsial berpengaruh terhadap kepuasan mahasiswa pengguna jasa perpustakaan pusat Universitas Merdeka Madiun. (2) Tingkat signifikansinya variabel reliability sebesar $0,000<$ dari 0,05 dengan hipotesis yang menyatakan bahwa reliability secara parsial berpengaruh terhadap kepuasan mahasiswa pengguna jasa perpustakaan pusat Universitas Merdeka Madiun. (3) Tingkat signifikansinya variabel responsiveness sebesar 0,004 < dari 0,05 dengan hipotesis yang menyatakan bahwa responsiveness secara parsial berpengaruh terhadap kepuasan mahasiswa pengguna jasa perpustakaan pusat Universitas Merdeka Madiun. (4) Tingkat signifikansinya variabel ansurance sebesar $0,170<$ dari 0,05 dengan hipotesis yang menyatakan bahwa ansurance secara parsial berpengaruh terhadap kepuasan mahasiswa pengguna jasa perpustakaan pusat Universitas Merdeka Madiun. (5) Tingkat signifikansinya variabel emphaty sebesar $0,000>$ dari 0,05 dengan hipotesis yang menyatakan bahwa emphaty secara parsial tidak berpengaruh terhadap kepuasan mahasiswa pengguna jasa perpustakaan pusat Universitas Merdeka Madiun.

\section{Distribusi F (F-ratio)}

Tabel 2

Analisa Of Varian (ANOVA)

\begin{tabular}{|c|c|c|c|c|c|}
\hline Model & $\begin{array}{c}\text { Sum of } \\
\text { Squares }\end{array}$ & df & Mean Square & $\mathbf{F}$ & Sig. \\
\hline $\begin{array}{ll}1 & \begin{array}{l}\text { Regressio } \\
\mathrm{n}\end{array}\end{array}$ & 3.511 & 5 & .702 & $\begin{array}{r}91.96 \\
2\end{array}$ & $.000^{\mathrm{a}}$ \\
\hline Residual & .687 & 90 & .008 & & \\
\hline Total & 4.198 & 95 & & & \\
\hline
\end{tabular}

a. Predictors: (Constant), X5, X2, X1, X4, X3

b. Dependent Variable: $\mathrm{Y}$

Hasil analisis pada Tabel 2 menunjukkan bahwa secara simultan variabel Tangible, reliability, responsiveness, assurance dan emphaty tingkat signifikansinya $0,000<$ dari 0,05 dengan hipotesis yang menyatakan bahwa Tangible, reliability, responsiveness, assurance dan emphaty secara simultan berpengaruh terhadap kepuasan mahasiswa pengguna jasa perpustakaan pusat Universitas Merdeka Madiun.

\section{Koefisien Determinasi (R2)}

Tabel 3

Koefisien Determinasi (R2)

\begin{tabular}{|l|r|r|r|r|}
\hline Model & R & R Square & $\begin{array}{c}\text { Adjusted R } \\
\text { Square }\end{array}$ & $\begin{array}{c}\text { Std. Error of the } \\
\text { Estimate }\end{array}$ \\
\hline 1 & $.914^{\mathrm{a}}$ & .836 & .827 & .08738 \\
\hline
\end{tabular}

Analisis Tabel 3 nilai $R$ Square $\left(\mathrm{R}^{2}\right)$ sebesar 0,836 ini menunjukan bahwa kontribusi besarnya pengaruh variabel-variabel independen (Tangible, reliability, responsiveness, assurance dan emphaty) terhadap variabel dependen (kepuasan mahasiswa pengguna jasa perpustakaan pusat Universitas Merdeka Madiun) sebesar 83,6\%. Sedangkan sisanya sebesar 26,4\% dipengaruhi oleh variabel lain.

\section{E. Variabel Dominan}

Hasil analisis Tabel 1 menunjukkan bahwa nilai Standardized Coefficients Beta tertinggi pada variabel responsiveness sebesar 0,564 maka variabel tersebut berpengaruh dominan terhadap kepuasan mahasiswa pengguna jasa perpustakaan pusat Universitas Merdeka Madiun. 
Website : http://ekomaks.unmermadiun.ac.id/index.php/ekomaks

\section{F. Pembahasan}

Lembaga perguruan tinggi terdiri dari beberapa unit pelayanan jasa. Salah satu unit pelayanan jasa tersebut adalah perpustakaan, apalagi jaman era informasi dan persaingan yang semakin ketat sekarang ini perpustakaan harus terus menerus dan mampu mengadakan perbaikan-perbaikan, baik dalam penyediaan informasi maupun dalam hal pelayanan. Perbaikan yang dilakukan agar perpustakaan tidak ditinggalkan oleh para pengguna, para pengguna jasa perpustakaan tidak hanya sekedar tempat mencari informasi, tetapi tertarik kembali lagi karena adanya pelayanan lebih yang tidak dimiliki oleh perpustakaan lainnya. Adanya pelayanan lebih tersebut menunjukan kualitas pelayanan yang diberikan pada para pengguna jasa perpustakaan/pemustaka.

Berdasarkan analisis menunjukkan bahwa temuan penelitian secara simultan kualitas pelayanan yang terdiri dari dimensi tangible, reliability, responsiveness, assurance dan emphaty berpengaruh terhadap kepuasan mahasiswa pengguna/pemustaka jasa perpustakaan pusat Universitas Merdeka Madiun. Berarti secara bersama-sama variabel kualitas pelayanan mampu mempengaruhi variasi kepuasan mahasiswa pengguna jasa perpustakaan pusat Universitas Merdeka Madiun.

Temuan ini memberi indikasi bahwa perbaikan dan peningkatan dalam penanganan mengenai kualitas pelayanan secara bersama-sama perlu perhatian yang sungguh-sungguh dan lebih serius untuk manjaga serta sekaligus meningkatkan jumlah pemustaka/mahasiswa pengguna jasa perpustakaan Universitas Merdeka Madiun. Kualitas pelayanan yang baik akan menimbulkan adanya image yang baik bagi pengguna/pemustaka tersebut, sehingga tertarik untuk kembali menggunakan jasa Perpustakaan Pusat Universitas Merdeka Madiun lagi.

Kelima variabel bebas yang diteliti dari segi pengaruhnya secara parsial terhadap kepuasan mahasiswa pengguna jasa perpustakaan pusat Universitas Merdeka Madiun dapat dijelaskan pada pembahasan sebagai berikut:

\section{Tangible/Bukti Fisik (XI)}

Tangible/bukti fisik secara parsial berpengaruh terhadap kepuasan mahasiswa pengguna jasa perpustakaan pusat Universitas Merdeka Madiun. Menunjukkan bahwa indikator berkenaan dengan daya tarik fasilitas fisik, perlengkapan, dan materi yang di gunakan perusahaan serta penampilan karyawan berpengaruh positif. Persepsi pemustaka/ mahasiswa pengguna jasa perpustakaan pusat Universitas Merdeka Madiun rata-rata memberikan pernyataan bahwa penataan meja kursi dalam ruang perpustakaan tertata rapi; buku dalam ruangan perpustakaan tertata dengan baik dan rapi; buku-buku yang disediakan lengkap dan up-date; dalam keadaan masih bagus-bagus; ruang perpustakaan bersih dan nyaman; perpustakaan menyediakan fasilitas internet, foto copi, sarana penelusuran informasi, loker barang; sirkulasi udara perpustakaan baik dan petugas perpustakaan berpakaian rapi dan sopan. Tangible/bukti fisik tersebut akan mempengaruhi terhadap kepuasan pemustaka/ mahasiswa pengguna jasa di perpustakaan pusat Universitas Merdeka Madiun.

\section{Reliability/Keandalan (X2)}

Reliability/keandalan secara parsial berpengaruh terhadap kepuasan mahasiswa pengguna jasa perpustakaan pusat Universitas Merdeka Madiun. Menunjukkan bahwa indikator berkenaan dengan kemampuan untuk memberikan layanan dengan segera, akurat, konsisten dan memuaskan berpengaruh positif. Persepsi pemustaka/ mahasiswa pengguna jasa perpustakaan pusat Universitas Merdeka Madiun rata-rata memberikan pernyataan bahwa petugas perpustakaan memberikan pelayanan yang baik untuk pengunjung; prosedur pelayanan mudah; jam buka perpustakaan sesuai dengan ketersediaan dan kebutuhan para pengunjung; jumlah maksimal peminjaman buku sesuai kebutuhan pengunjung; dan petugas memberikan informasi jasa layanan dan fasilitas perpustakaan dengan baik. Reliability/keandalan tersebut akan mempengaruhi terhadap kepuasan pemustaka/ mahasiswa pengguna jasa di perpustakaan pusat Universitas Merdeka Madiun.

\section{Responsiveness/Daya Tanggap (X3)}

Responsiveness/daya tanggap secara parsial berpengaruh terhadap kepuasan mahasiswa pengguna jasa perpustakaan pusat Universitas Merdeka Madiun. Ini menunjukkan bahwa indikator berkenaan dengan kesedian untuk membantu pelanggan dan memberikan pelayanan dengan segera dan tepat berpengaruh positif. Persepsi pemustaka/ mahasiswa pengguna jasa perpustakaan pusat Universitas Merdeka Madiun rata-rata memberikan pernyataan bahwa pemustaka segera memperoleh pelayanan untuk meminjam buku; petugas perpustakaan selalu bersedia melayani permintaan; tidak menunggu dalam antrian sangat lama; petugas menunjukan kesungguhan membantu bila terjadi masalah; petugas layanan siap dan sigap dalam melayani. Responsiveness/daya tanggap tersebut akan mempengaruhi terhadap kepuasan pemustaka/ mahasiswa pengguna jasa di perpustakaan pusat Universitas Merdeka Madiun.

\section{Assurance/Jaminan (X4)}

Assurance/jaminan secara parsial tidak berpengaruh terhadap kepuasan mahasiswa pengguna jasa perpustakaan pusat Universitas Merdeka Madiun. Ini menunjukkan bahwa indikator berkenaan dengan pengetahuan, keramahan, serta kemampuan karyawan untuk menimbulkan kepercayaan pelanggan terhadap perusahaan berpengaruh negatif. Persepsi pemustaka/ mahasiswa pengguna jasa perpustakaan pusat Universitas Merdeka Madiun rata-rata memberi pernyataan kurang puas mengenai jam layanan yang dijanjikan; kemampuan menjawab semua pertanyaan pengunjung; pengetahuan dan kemampuan dalam memberikan informasi bagi pengunjung dan barang-barang bawaan pengunjung terjamin serta tersimpan rapi dan aman 
dalam loker. Assurance/jaminan tersebut akan mempengaruhi terhadap kepuasan pemustaka/ mahasiswa pengguna jasa di perpustakaan pusat Universitas Merdeka Madiun.

\section{Emphaty/Kemampuan (X5)}

Emphaty/kemampuan secara parsial tidak berpengaruh terhadap kepuasan mahasiswa pengguna jasa perpustakaan pusat Universitas Merdeka Madiun. Ini menunjukkan bahwa indikator berkenaan dengan perhatian secara individu yang diberikan oleh penyedia jasa sehingga pelanggan merasa penting, dihargai, dan dimengerti oleh perusahaan berpengaruh positif. Persepsi pemustaka/ mahasiswa pengguna jasa perpustakaan pusat Universitas Merdeka Madiun bahwa pemustaka mendapatkan perhatian petugas walaupun sendirian; mendapatkan informasi dan petunjuk tata cara pemanfaatan layanan yang diberikan dengan jelas; petugas membantu dalam pencarian buku yang diperlukan; petugas menanggapi keluhan dan saran pemustaka dengan baik dan petugas memahami kebutuhan pemustaka secara spesifik. Emphaty/Kemampuan tersebut akan mempengaruhi terhadap kepuasan pemustaka/ mahasiswa pengguna jasa di perpustakaan pusat Universitas Merdeka Madiun.

\section{IV.KESIMPULAN}

Hasil temuan penelitian yang telah dilakukan, dapat diperoleh kesimpulan sebagai berikut:

1) Tangible, Reliability, Responsiveness dan Emphaty secara parsial berpengaruh terhadap kepuasan mahasiswa pengguna perpustakaan pusat Universitas Merdeka Madiun.

2) Assurance secara parsial tidak berpengaruh terhadap kepuasan mahasiswa pengguna perpustakaan pusat Universitas Merdeka Madiun.

3) Tangible, reliability, responsiveness, assurance dan emphaty secara simultan berpengaruh terhadap kepuasan mahasiswa pengguna perpustakaan pusat Universitas Merdeka Madiun.

Berdasarkan hasil temuan penelitian secara simultan kualitas pelayanan berpengaruh positif terhadap kepuasan para pengunjung perpustakaan pusat Universitas Merdeka Madiun, namun secara parsial Assurance/jaminan berpengaruh negatif terhadap kepuasan para pengunjung perpustakaan pusat Universitas Merdeka Madiun. Bagi pihak manajemen sebaiknya kualitas pelayanan lebih ditingkatkan lagi khususnya mengenai assurance/jaminan dengan menambah sumber daya manusia Perpustakaan Pusat Universitas Merdeka Madiun dari lulusan sarjana Perpustakaan. Jumlah petugas tercukupi dapat menambah jam layanan, dengan ilmu pengetahuan yang dimiliki akan mampu menjawab semua pertanyaan dan mampu memberikan informasi bagi pengunjung.

Petugas perpustakaan pusat Universitas Merdeka Madiun diharapkan lebih intensif untuk terus mengembangkan diri sesuai dengan potensi yang dimiliki dan memanfaatkan fasilitas-fasilitas yang ada di perpustakaan sehingga petugas tersebut akan dapat menciptakan kualitas pelayanan yang baik. Karena kualitas pelayanan sangat berpengaruh terhadap kepuasan mahasiswa pengguna/pemustaka jasa perpustakaan pusat Universitas Merdeka Madiun.

\section{DAFTAR PUSTAKA}

Assegaff, Mohammad. 2009. Pengaruh Kualitas Pelayanan Terhadap Kepuasan Pelanggan. Jurnal EKOBIS, Vol. 10, NO. 2.

Griselda, Gretel dan Tagor Muda Panjaitan. 2007. Analisis Pengaruh Kualitas Pelayanan Terhadap Kepuasan Konsumen Restoran Pulau Dua. Derema Jurnal Manajemen, Vol. 2, No. 1.

Kotler, dan Keller. 2012. Manajemen Pemasaran. Edisi 12. Erlangga, Jakarta.

Kotler, Philip. \& Gary Armstrong. 2014. Principle Of Marketing, 15th Edition. Pearson Prentice Hall, New Jersey.

Tjiptono, Fandy dan Gregorus Chandra. 2005. Service, Quality, Satisfaction. Andi, Yogyakarta.

Tjiptono, Fandy. 2014. Pemasaran Jasa-Prinsip, Penerapan, dan Penelitian. Andi Offset, Yogyakarta. 